\title{
PENYULUHAN PENGGUNAAN SOSIAL MEDIA UNTUK KEPARIWISATAAN DESA BATULAYAR, KABUPATEN LOMBOK BARAT, NTB
}

\section{(Counseling the Use of Social Media For Tourism in Batulayar, Lombok Barat, NTB)}

\author{
Gibran Satya Nugraha $^{[1]}$, I Gede Pasek Suta Wijaya ${ }^{[1]}$, Fitri Bimantoro ${ }^{[1]}$, Ario Yudo Husodo ${ }^{[1]}$, Arik \\ Aranta $^{[1]}$ \\ ${ }^{[1]}$ Program Studi Teknik Informatika, Universitas Mataram \\ Jl. Majapahit 62, Mataram, Lombok NTB, INDONESIA \\ Email: [gibransn, gpsutawijaya, bimo, ario, arikaranta]@unram.ac.id
}

\begin{abstract}
Abstrak
Sosial media adalah salah satu alternatif yang digunakan para pelancong untuk mempublikasikan keindahan lokasi wisata yang mereka kunjungi, terutama yang ada di pulau Lombok. Media sosial yang banyak digunakan warga Desa Batulayar adalah Facebook dan Instagram. Mengenai daerah wisata, walaupun Desa Batulayar tidak memiliki daerah pantai namun Desa Batulayar memiliki pariwisata yang cukup menjanjikan yaitu Embung Teloke yang ada di Dusun Orong. Namun masih banyak masyarakat luar yang tidak mengetahui keberadaan Embung Teloke ini. Dikarenakan belum sadarnya masyarakat akan kegunaan sosial media untuk menyebarluaskan informasi daerah wisata yang mereka miliki. Sedikitnya warga masyarakat yang berperan dalam menyebarkan informasi melalui sosial media juga menjadi kendala kurang terkenalnya daerah wisata di Desa Batulayar. Dari permasalahan yang sudah dijelaskan tersebut dibutuhkan sebuah kegiatan penyuluhan yang berkaitan dengan penggunaan media sosial untuk mempromosikan daerahdaerah wisata khususnya di Desa Batulayar. Kegiatan ini diharapkan dapat membantu warga Desa Batulayar untuk lebih aktif dalam menggunakan sosial media yang dimilikinya untuk mempromosikan daerah wisata di Batulayar sehingga tempat-tempat wisata tersebut akan ramai dikunjungi yang tentunya akan meningkatkan pendapatan warga. Melalui kegiatan penyuluhan penggunaan sosial media untuk kepariwisataan ini target luaran yang diharapkan adalah masyarakat dapat memanfaatkan sosial media dalam melakukan promosi secara tepat,
\end{abstract}

Keywords: pariwisata, Batulayar, sosial media, Instagram.

\section{Pendahuluan}

Pulau Lombok terkenal sebagai destinasi wisata yang indah di Indonesia bahkan di dunia. Lombok dikenal dengan julukan Pulau Seribu Masjidnya. Pulau Lombok pernah dinobatkan sebagai World Best Halal Tourism Destination dan World Best Halal Honeymoon Destination pada tahun 2015 dalam acara World Halal Travel Summit 2015 yang diadakan di Abu Dhabi, UEA. Mengalahkan beberapa negara pesaing dalam kategori yang sama. Pulau Lombok terpilih berdasarkan hasil voting yang dilakukan secara online [1].

Wisatawan lokal dan mancanegara dari tahun ke tahun selalu bertambah. Tujuan utama para wisatawan tersebut adalah gili atau pulau kecil yang ada di sekitar pulau Lombok, pantainya yang cukup terkenal seperti Pantai Kuta dan wisata air terjun seperti Air Terjun Benang Stokel atau Benang Kelambu. Tidak lupa pula untuk yang hobi mendaki, Gunung Rinjani selalu terlihat megah untuk ditaklukan para pendaki yang datang berkunjung [1]

Perjuangan pulau Lombok agar menjadi tujuan destinasi wisata yang cukup terkenal seperti sekarang adalah tidak luput dari jasa para pelancong yang berkunjung ke pulau Lombok. Karena di era internet yang sudah cukup berkembang pesat serta hadirnya beberapa platform sosial media yang bisa digunakan para pelancong untuk mempublikasikan keindahan lokasi wisata yang mereka kunjungi, terutama yang ada di pulau Lombok [2].

Desa Batulayar adalah sebuah desa di Kecamatan Batulayar, Kabupaten Lombok Barat yang berjarak sekitar $10 \mathrm{Km}$ dari pusat kota Mataram. Kecamatan Batulayar memiliki pantai yang cukup terkenal yaitu Pantai Senggigi. Sejauh ini penggunaan sosial media di Desa Batulayar sudah cukup banyak, bahkan hampir di semua wilayah (dusun). Sosial media digemari oleh seluruh kalangan umur mulai dari kalangan remaja, anak-anak, dan orang tua sudah sangat akrab dengan sosial media terutama setelah adanya kelompok perempuan kaukus. 
Data Pengguna Telepon, Internet, Media Sosial Indonesia Menurut Wearesosial (2019)

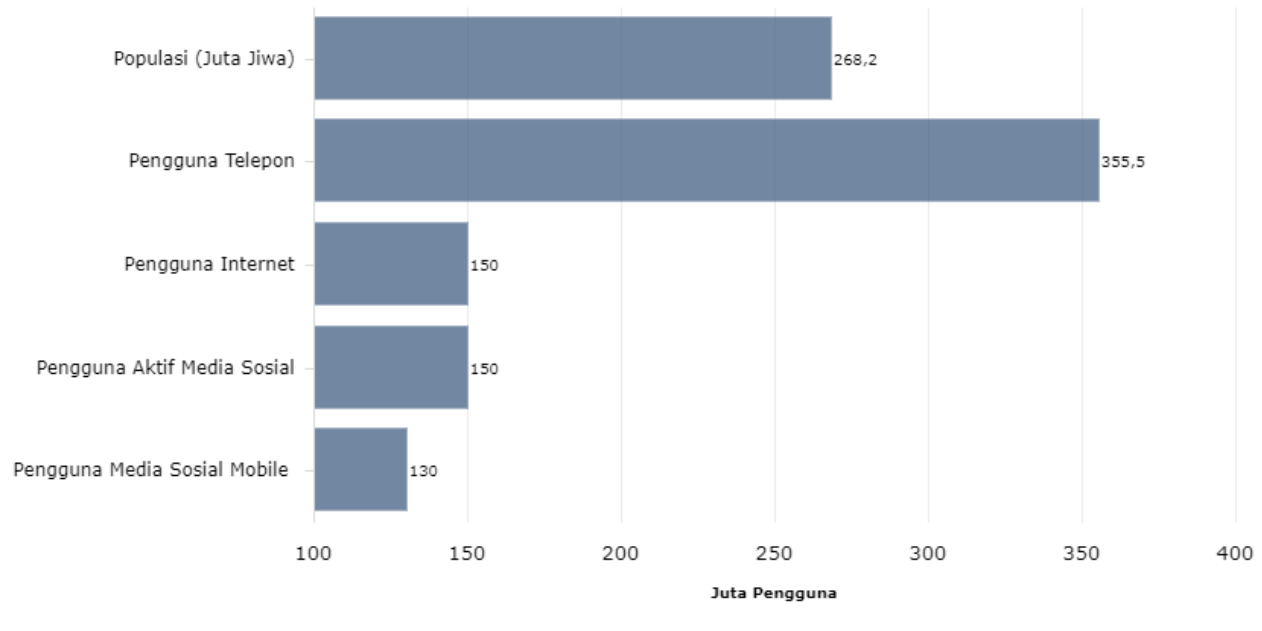

Dkatadata

Gambar 1. Data pengguna telepon, internet, dan media sosial [3]

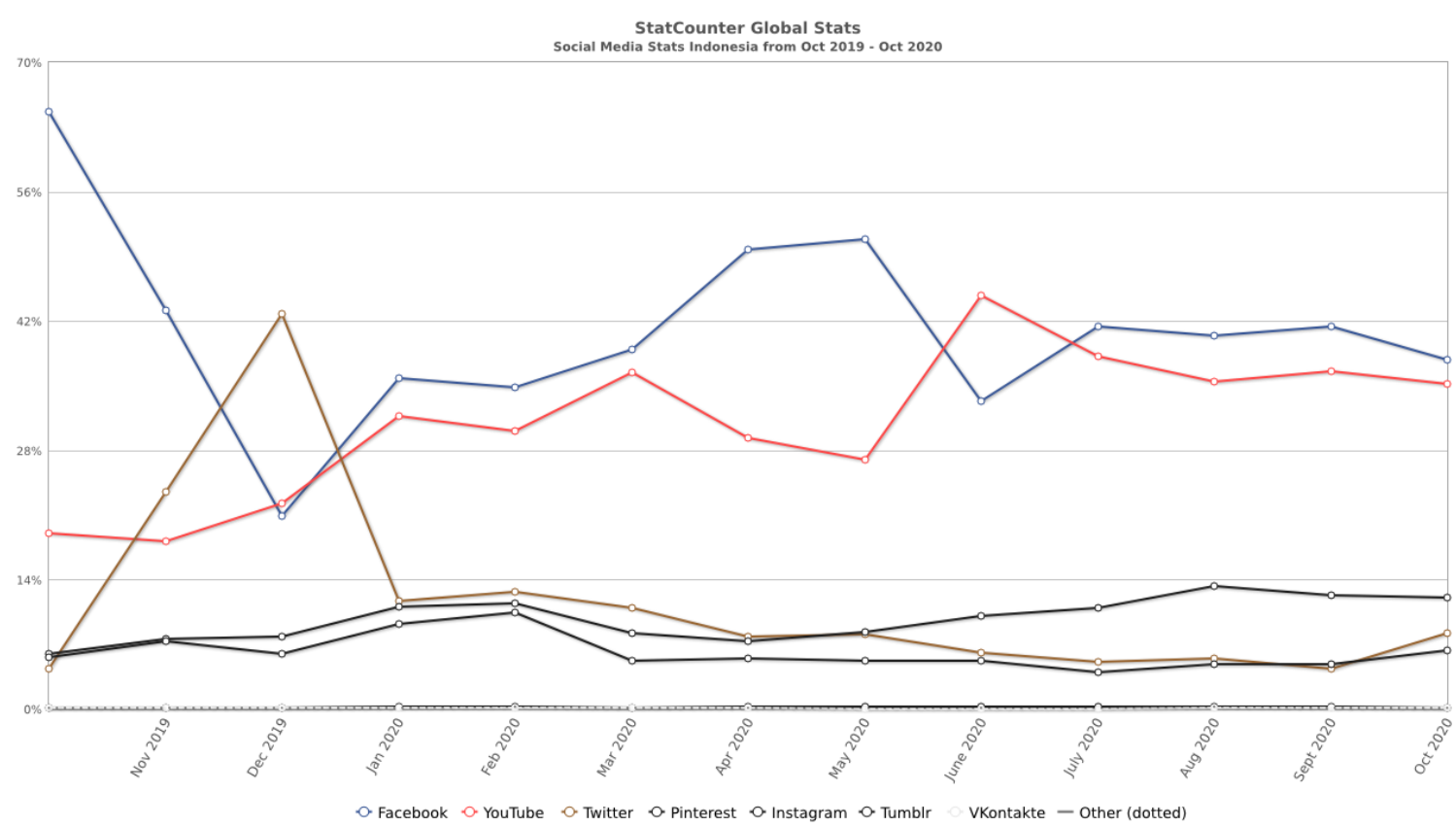

Gambar 2. Pengguna media sosial di Indonesia [4]

Pada Gambar 1 dan Gambar 2 terlihat jumlah pengguna sosial media sangat tinggi yang diikuti dengan jumlah pengguna aktif dan pengguna media sosial melalui perangkat mobile. Hal ini membuktikan peran media sosial sangat besar dalam kehidupan sehari-hari. Pulau Lombok sendiri termasuk menjadi salah satu destinasi pariwisata yang paling banyak dikunjungi pada 2019 [5], hal tersebut tidak terlepas dari respon wisatawan melalui media sosial terhadap pariwisata yang ada di Lombok.

Media sosial yang banyak digunakan warga Desa Batulayar adalah Facebook. Selain Facebook, warga Desa Batulayar juga menggunakan Instagram, namun mayoritas yang menggunakannya adalah dari kalangan remaja. Selain untuk keperluan pribadi, warga desa Batulayar menggunakan sosial media untuk berbagai macam keperluan seperti berdagang, membuat grup desa, grup remaja, promosi pariwisata, dan lain-lain. Mengenai daerah wisata, walaupun Desa Batulayar tidak memiliki daerah pantai namun Desa Batulayar memiliki pariwisata yang cukup menjanjikan yaitu Embung Teloke yang ada di Dusun Orong. 
Embung Teloke adalah sejenis bendungan mini yang berfungsi menampung air untuk menjadi sumber air untuk warga sekitar. Embung Teloke sejauh ini telah berdiri dan dikelola secara swadaya oleh masyarakat. Namun masih banyak warga masyarakat luar yang tidak mengetahui keberadaan Embung Teloke ini. Dikarenakan belum sadarnya masyarakat akan kegunaan sosial media untuk menyebarluaskan informasi daerah wisata yang mereka miliki. Sedikitnya warga masyarakat yang berperan dalam menyebarkan informasi melalui sosial media juga menjadi kendala kurang terkenalnya daerah wisata di Desa Batulayar. Adapun yang sekarang masih berperan aktif menyebarkan pariwisata melalui sosial media hanya dari kalangan agen perjalanan dan pemandu wisata, namun jumlahnya masih sangat sedikit, yaitu kurang dari 5 orang.

Dari permasalahan yang sudah dijelaskan tersebut dibutuhkan sebuah kegiatan penyuluhan yang berkaitan dengan menggunakan media sosial untuk mempromosikan daerah-daerah wisata khsususnya di Desa Batulayar. Kegiatan ini diharapkan dapat membantu warga Desa Batulayar untuk lebih aktif dalam menggunakan sosial media yang dimilikinya untuk mempromosikan daerah wisata di Batulayar sehingga tempat-tempat wisata tersebut akan ramai dikunjungi yang tentunya akan meningkatkan pendapatan warga. Tujuan dari kegiatan penyuluhan penggunaan sosial media untuk kepariwisataan ini adalah:

a. Memberikan penjelasan tentang media sosial dan bagaimana memanfaatkannya secara baik dan benar.

b. Mensosialisasikan jenis-jenis konten yang terdapat dalam sosial media untuk menarik perhatian pengguna internet

c. Memberikan penjelasan tentang etika ber-sosial media secara sehat agar terhindar dari dampak negatif dan memaksimalkan dampak positifnya.

d. Memberikan penjelasan tentang konsekuensi hukum dari berinternet yang tidak sehat terutama di sosial media.

e. Memberikan tip-tip dalam berkomunikasi dan berinteraksi secara sehat di dunia maya. berikut:

Adapun manfaat dari kegiatan penyuluhan penggunaan sosial media untuk kepariwisataan ini adalah sebagai

a. Bagi warga Desa Batulayar dalam mempromosikan daerah wisatanya dapat memanfaatkan sosial media untuk mempromosikan, memberikan informasi yang menarik, serta untuk mempopulerkan usaha atau bisnis yang ditekuni.

b. Bagi warga Desa Batulayar dalam melakukan promosi di sosial media mengetahui etikanya dan mengamalkannya agar terhindar dari kasus pelanggaran hukum dalam dunia maya.

Berdasarkan uraian tentang pemanfaatan media sosial untuk kepariwisataan, maka diperlukan suatu upaya untuk menjadikan sosial media sebagai wahana untuk memperkenalkan daerah wisata serta untuk memberikan informasi yang bermanfaat pagi wisatawan. Oleh karena itu penyuluhan penggunaan sosial media untuk kepariwisataan perlu dilakukan kepada masyarakat luas baik anak-anak, remaja, maupun orang dewasa

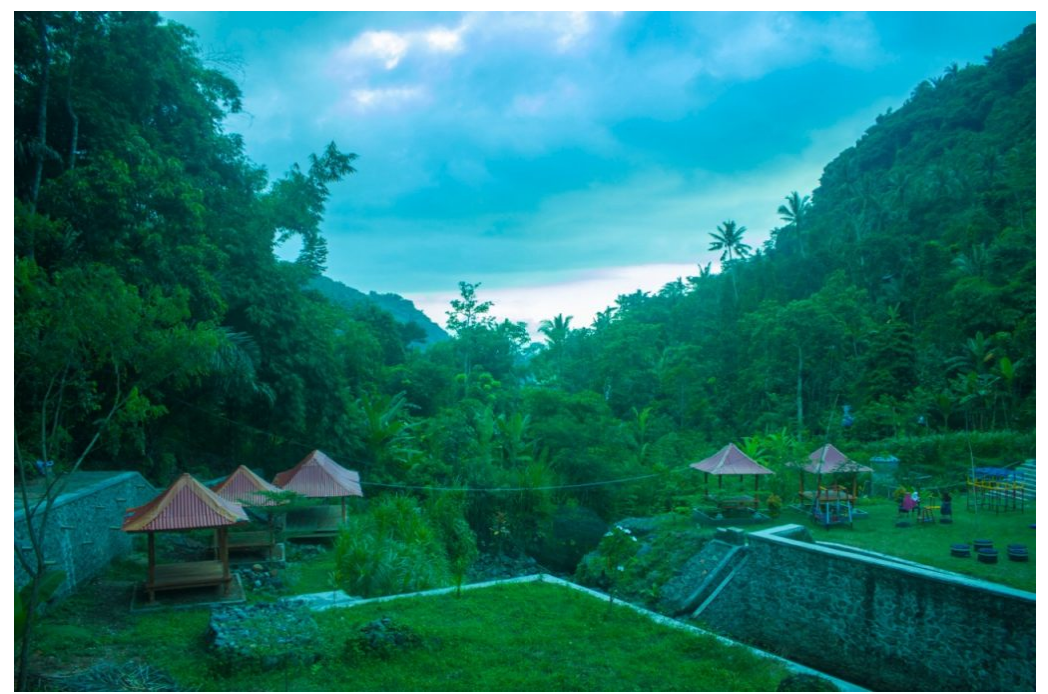

Gambar 3. Embung Teloke di Desa Batulayar [6] 


\section{Tinjauan PUStaka}

Beberapa artikel ilmiah mengenai pemanfaatan sosial media untuk kepariwisataan sudah pernah dilakukan. Setiawan, dkk [7] melakukan kajian mengenai unsur kepariwisataan melalui sebuah buku. Buku tersebut berisi halhal yang berkaitan dengan tone warna, media, display yang menunjang bagaimana sebuah kepariwisataan bisa dipromosikan dalam sebuah media sosial.

Rifiyan, dkk [8] membahas mengenai pelaksanaan promosi kepariwisataan Samosir yang dilakukan dengan kolaborasi berbagai pihak. Pariwisata menawarkan dua komponen utama yaitu objek dan daya tarik wisata berbasis alam, budaya maupun minat khusus. Menurut Rifiyan, dkk sebuah destinasi wisata tidak hanya menawarkan objek saja, melainkan segala hal yang dapat menarik wisatawan dan masih berada dalam daerah wisata tersebut. Promosi merupakan sebuah usaha untuk memberitahukan dan menawarkan produk yang diikuti dengan bujukan bagi konsumen untuk mengkonsumsi produk tersebut.

Sudarmadi [9], mengumpulkan data profil wilayah dan objek-objek yang berpotensi untuk dikembangkan sebagai tujuan wisata di Desa Pengkol, Sukoharjo, Jawa Tengah. Selain data tersebut dikumpulkan juga informasi yang berkaitan dengan sarana dan prasarana, aspek sosial, ekonomi, dan budaya. Data primer juga diperkuat dengan data sekunder yang diperoleh dari referensi-referensi yang berkaitan dengan artikel, buku, dan sumber-sumber tertulis tentang kesejahteraan wilayah Sukaharjo.

Kurniasari [10], melakukan kajian mengenai strategi penanganan krisis kepariwisataan dalam Kebijakan Badan Nasional Penanggulangan Bencana (BNPB). Bencana alam yang melanda destinasi wisata Indonesia adalah serangkaian peristiwa yang menciptakan ketidakpastian. Bencana terjadi ketika ketidaksiapan sumber daya yang ada dalam mengatasi ancaman sehingga menyebabkan kerugian yang salah satunya berdampak pada daerah wisata. Setiap daerah selayaknya harus bersiap dengan kondisi tersebut, sehingga dapat meminimalisir dampak bencana alam terhadap daerah wisata,

Luckvani [11], melakukan penelitian mengenai pengaruh kualitas informasi kepariwisataan di media sosial daring Facebook dan Instagram pada citra destinasi wisata. Teknik pengumpulan data dan teknik analisis melalui pendekatan kuantitatif dengan instrumen kuesioner yang disebarkan melalui media daring. Metode analisis pada riset ini menggunakan metode analisis regresi sederhana dan analisis regresi berganda dengan menggunakan SPSS Penelitian tersebut memperoleh data variabel relevansi, daya tarik, dan jumlah informasi berpengaruh signifikan terhadap pembentukan citra kognitif.

Larita, dkk [12] membahas mengenai pemanfaatan media sosial Instagram sebagai media promosi Dinas Kebudayaan dan Kepariwistaan Sulawesi Selatan. Media sosial dapat digunakan oleh para wisatawan untuk membagikan pengalaman berkunjung mereke ke suatu tempat, hal tersebut sangat berguna bagi orang lain yang akan berkunjung ke daerah tersebut karena mendapatkan tambahan informasi yang sangat bermanfaat. Selain sebagai media promosi, media sosial juga dimanfaatkan sebagai untuk kepentingan bisnis.

Sosial media memiliki peranan penting bagi pihak-pihak tertentu untuk mengetahui respon masyarakat terhadap sesuatu yang dipublikasikan di sosial media. Hal ini juga berlaku bagi para pelaku bisnis bidang pariwisata, yang dimana respon para pengguna sosial media sangat berpengaruh terhadap minat wisatawan terhadap unsur pariwisata yang ditawarkan. Respon tersebut berupa sebuah analisis sentiment. Penelitan tentang analisis sentimen mengenai pariwisata Lombok dilakukan oleh Ulfa, dkk [13] dengan menggunakan data dari media sosial Twitter.

Informasi mengenai respon masyarakat di sosial media akan sangat berguna sebagai dasar evaluasi untuk membenahi sektor pariwisata yang dipromosikan. Informasi tersebut akan semakin baik apabila disimpan dalam sebuah website atau sistem informasi sehingga penyampaian dan penulisan informasi menjadi lebih efektif dan efisien [14].

\section{Metode Pengabdian MaSyarakat}

Solusi yang ditawarkan pada kegiatan penyuluhan penggunaan sosial media untuk kepariwisataan ini adalah sebagai berikut :

a. Memberikan penyuluhan tentang pemanfaatan media sosial dan untuk membuka wawasan baru yang terkait dengan bidang pariwisata travelling maupun pengembangan enterpreneurship.

b. Melakukan tutorial tentang pemanfaatan fitur-fitur pada media sosial seperti posting, share, dll

c. Memberikan penjelasan tentang pentingnya etika dalam menggunakan media sosial

d. Memberikan pemahaman pengaruh negatif dari penggunaan media sosial apabila dilakukan untuk hal-hal yang tidak semestinya layak dilakukan

Sasaran kegiatan penyuluhan penggunaan sosial media untuk kepariwisataan adalah masyarakat Desa Batulayar khususnya generasi muda dan aparat pemerintahan desa (sekaligus orang tua dari generasi muda tersebut), sehingga masyarakat dapat memaksimalkan media sosial untuk mempromosikan daerah wisatanya. 
Kegiatan ini merupakan salah satu bentuk kepedulian Universitas Mataram, khususnya Program Studi Teknik Informatika Fakultas Teknik kepada masyarakat Desa Batulayar dalam pemanfaatan media sosial untuk kepariwisataan. Di samping itu, kegiatan penyuluhan ini sebagai sarana promosi lembaga perguruan tinggi khususnya Prodi Teknik Informatika kepada masyarakat, sehingga masyarakat yang tertarik menyekolahkan putraputrinya di bidangan teknologi informasi dapat menyekolahkannya di Universitas Mataram.

Kegiatan penyuluhan ini dilaksanakan secara bertahap yang diawali dengan survei lokasi dan meminta kesediaan masyarakat untuk mengikuti penyuluhan. Selanjutnya, secara teknis pelaksanaan kegiatan ini berupa penyuluhan dan diskusi tentang media sosial untuk kepariwisataan. Adapun peralatan yang diperlukan:

a. Seperangkat komputer yang terhubung dengan internet;

b. LCD projector; dan

c. Materi pelatihan.

d. Snack sebagai perangsang kegiatan

Materi yang akan diajarkan pada penyuluhan ini berkaitan dengan

a. Pengaruh sosial media dalam kehidupan sehari-hari

b. Alasan menggunakan sosial media untuk kepariwisataan

c. Sosial media yang paling banyak digunakan dalam bidang kepariwisataan

d. Informasi yang dibutuhkan oleh para wisatawan sebelum berkunjung ke suatu tempat wisata

e. Hal-hal yang tidak boleh dilakukan ketika mempromosikan suatu tempat wisata di media sosial

f. Tips melakukan sharing informasi suatu daerah wisata agar dapat menguntungkan calon wisatawan maupun masyarakat yang tinggal di daerah wisata tersebut

g. Respon positif dan negatif tentang pariwisata di Lombok

Evaluasi kegiatan penyuluhan media sosial untuk kepariwisataan dilaksanakan pada saat pelaksanaan kegiatan dengan melihat partisipasi peserta dalam mengikuti penyuluhan, pemahaman materi, dan mempraktekkan proses promosi daerah wisata melalui media sosial. Disamping itu, komunikasi lanjutan dapat dilakukan melalui email, WA, Facebook untuk melakukan diskusi tentang media sosial untuk kepariwisataan.

\section{HASIL DAN PEMBAHASAN}

Berdasarkan kegiatan pengabdian masyarakat yang sudah dilakukan terhadap masyarakat Desa Batulayar, diketahui bahwa pemanfaatan sosial media untuk kepariwisataan belum dilakukan secara maksimal sehingga promosi kepariwisataan di Desa Batulayar relatif belum berkembang.

Pemateri memberikan penjelasan terhadap materi yang disampaikan dalam bentuk diskusi dan juga melalui media pra-tayang. Kegiatan penyuluhan yang dilakukan mendapatkan respon dan antusiasme positif dari masyarakat mengenai diskusi tentang pemanfaatan sosial media untuk kepariwisataan, hal tersebut dapat dilihat pada Gambar 3, Gambar 4, dan Gambar 5. Dalam kegiatan penyuluhan yang dilakukan oleh tim, penjelasan materi disampaikan secara langsung menggunakan slide PowerPoint, seperti yang dapat dilihat pada Gambar 6 dan Gambar 7.

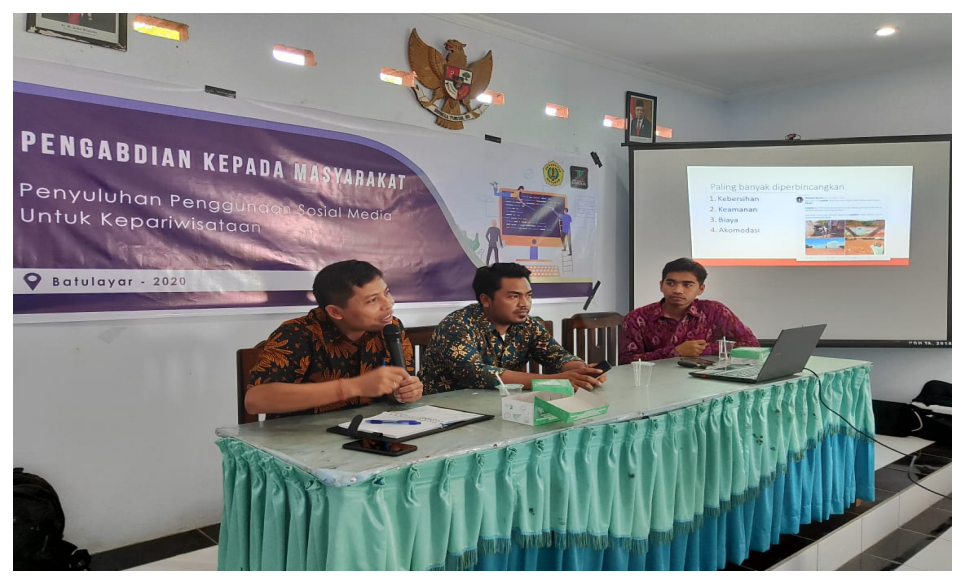

Gambar 3. Pemaparan hasil kajian oleh tim pemateri 


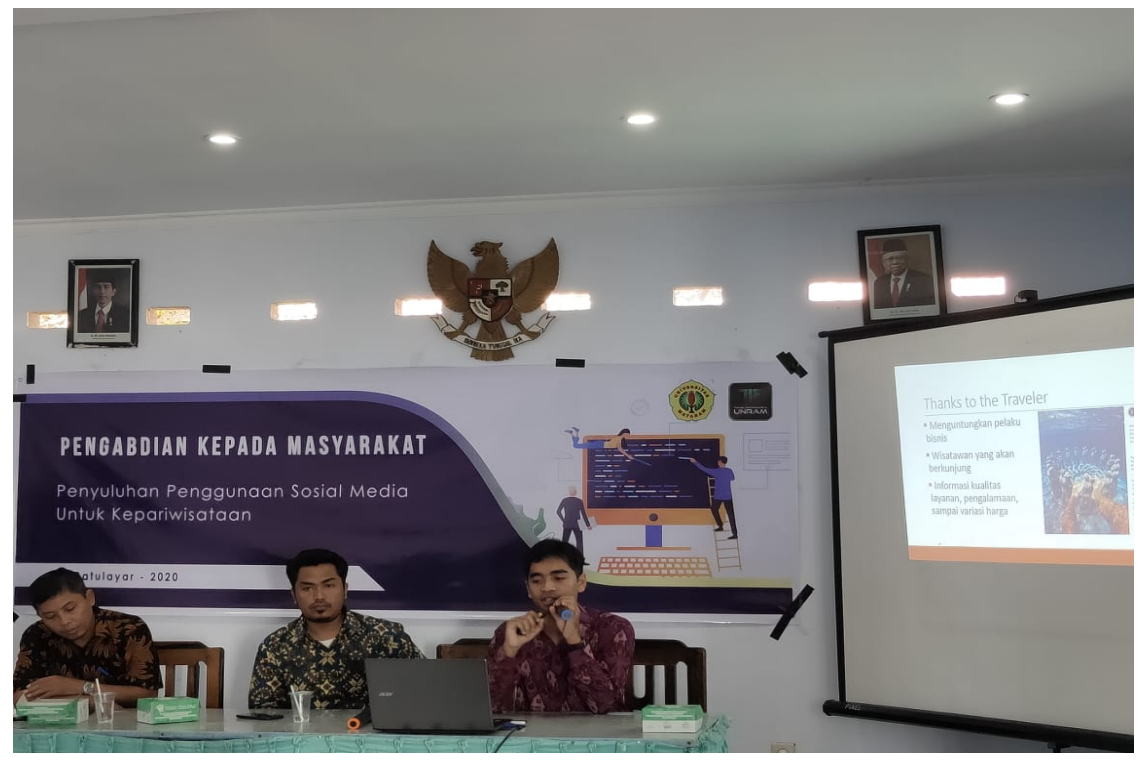

Gambar 4. Pemateri memberikan penjelasan secara lisan dan tulisan

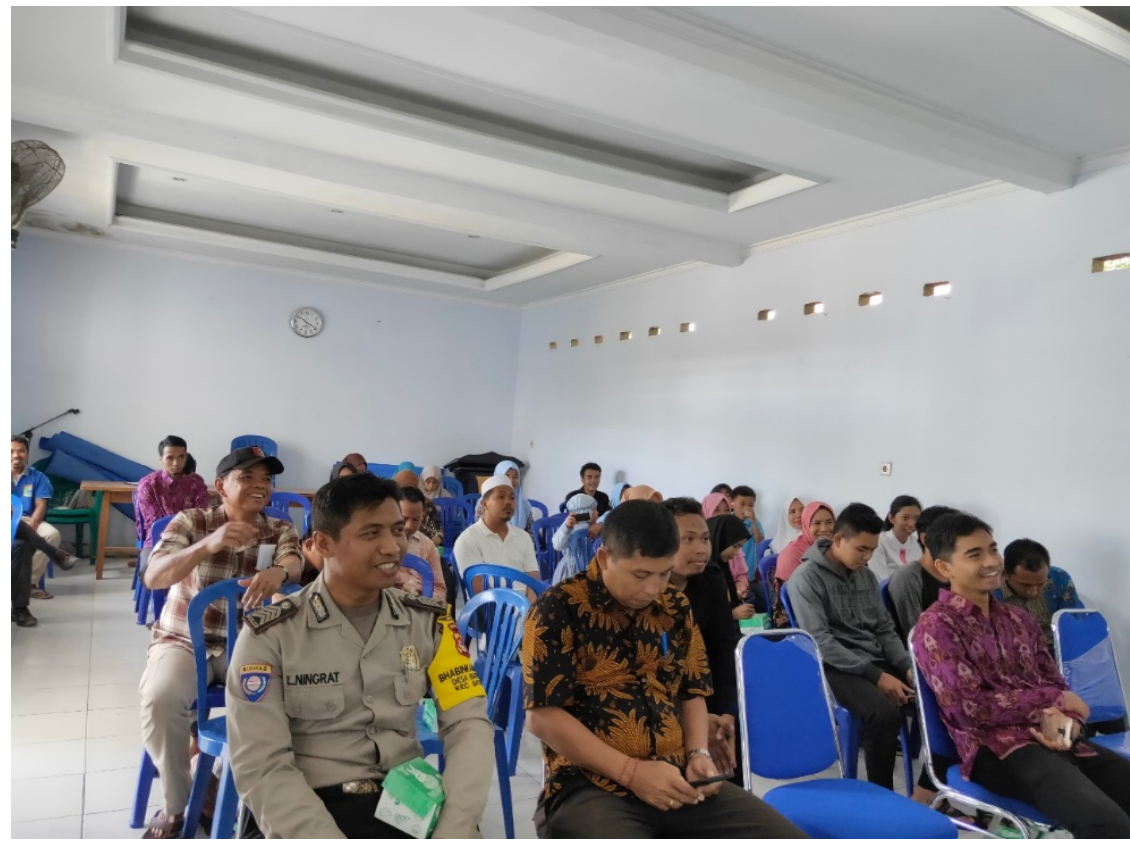

Gambar 5. Antusiasme peserta penyuluhan

Beberapa alasan menggunakan sosial media seperti yang dijelaskan pada slide ialah sebagai berikut:

a. Sosial media memudahkan dalam berkomunikasi

Dengan adanya sosial media membuat para pengunjung atau wisatawan mengetahui segala informasi yang dibutuhkan ketika akan berkunjunga ke suatu tempat wisata. Para pengunjung dapat menanyakan secara langsung informasi apa yang mereka butuhkan ke pelaku bisnis daerah pariwisata tersebut

b. Konten-konten menarik berupa teks, gambar, audio, dan video menjadi mudah tersampaikan

Salah satu daya tarik pengunjung wisata adalah gambar, audio, dan video tentang suatu daerah yang akan dikunjungi, dengan adanya media sosial para pelaku dunia pariwisata dapat dengan mudah mempromosikan daerahnya

c. Sosial media menjadi sarana promosi yang interaktif

Salah satu kelebihan dari media sosial adalah bisa menjadi sarana yang interaktif untuk melakukan promosi

d. Dunia pariwisata juga sangat "bergantung" terhadap sosial media 


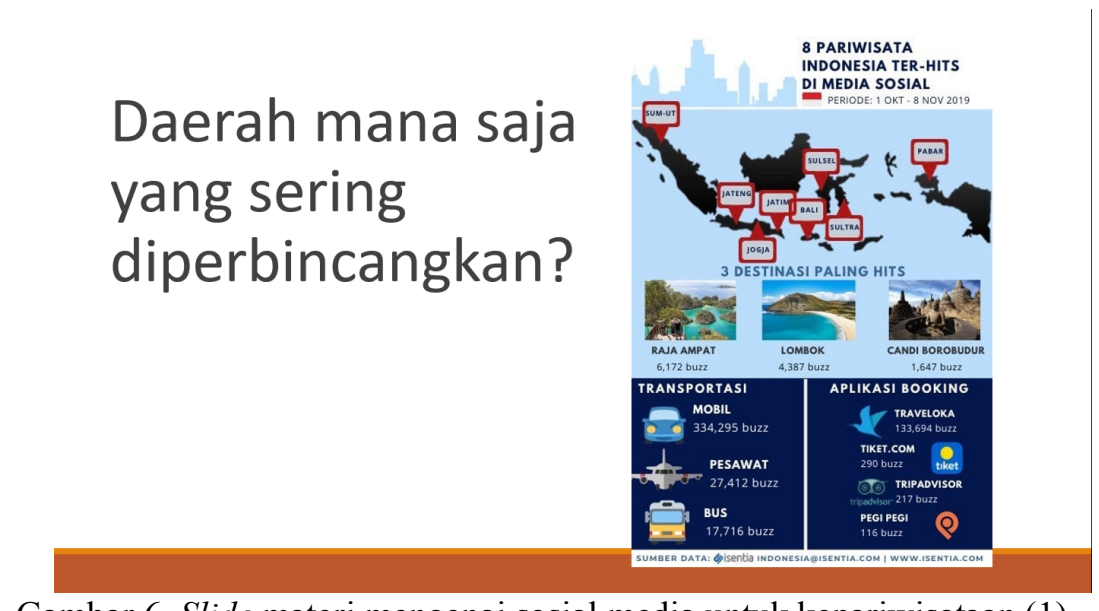

Gambar 6. Slide materi mengenai sosial media untuk kepariwisataan (1)

\section{Alasan menggunakan sosial media}

- Sosial media memudahkan dalam berkomunikasi

- Konten-konten menarik berupa teks, gambar, audio, dan video menjadi mudah tersampaikan

- Sosial media menjadi sarana promosi yang interaktif

- Dunia pariwisata juga sangat "bergantung" terhadap sosial media

Gambar 7. Slide materi mengenai sosial media untuk kepariwisataan (2)

\section{KESIMPULAN DAN SARAN}

Berdasarkan hasil pengamatan dari kegiatan pengabdian kepada masyarakat yang telah dilakukan, maka dapat disimpulkan hal-hal sebagai berikut :

a. Kegiatan pengabdian masyarakat dapat berjalan dengan baik dengan adanya komunikasi yang terjalin secara aktif antara tim pengabdian dan perangkat Desa Batulayar

b. Kegiatan pengabdian yang dilakukan sebagai bentuk upaya untuk mengedukasi masyarakat Desa Batulayar mengenai pemanfaatan sosial media untuk kepariwisataan

c. Materi yang disampaikan dapat menarik perhatian masyarakat yang hadir pada kegiatan tersebut karena disajikan dalam berbagai media, seperti audio dan video.

Untuk maksimalnya hasil kegiatan pengabdian masyarakat, maka diberikan saran-saran sebagai berikut:

a. Kegiatan pengabdian masyarakat dengan tema sejenis perlu dilaksanakan di daerah-daerah lain di Lombok Barat, sehingga perkembangan ilmu pengetahuan semakin baik

b. Komunikasi yang lebih aktif antara tim pengabdian dan perangkat desa diperlukan sehingga dapat dilakukan evaluasi secara berkesinambungan terhadap kegiatan yang dilakukan.

\section{UCAPAN TERIMA KASIH}

Tim pengabdian kepada masyarakat mengucapkan terima kasih kepada Lembaga Penelitian dan Pengabdian Kepada Masyarakat Universitas Mataram yang telah memberikan pendanaan dengan No:2009/UN18/LPPM/2020. 


\section{DAFTAR PUSTAKa}

[1] R. A. Putra, "Twitter Sentiment Analysis pada Sektor Pariwisata di Pulau Lombok dengan Metode Naive Bayes Classifier," Universitas Bumigora, 2019.

[2] A. A. Rizal, G. S. Nugraha, M. Tajuddin, A. B. Maulachela, and R. A. Putra, "Twitter Sentiment Analysis in Lombok Tourism with Polynomial Naïve Bayes Classifier," in The 1st International Scientific, Educational and Technological Conference (ISET-Con) 2019, 2019.

[3] D. H. Jayani, "Berapa Pengguna Internet di Indonesia?," 2019. [Online]. Available: https://databoks.katadata.co.id/datapublish/2019/09/09/berapa-pengguna-internet-di-indonesia.

[4] "Social Media Stats Indonesia | StatCounter Global Stats." [Online]. Available: https:/gs.statcounter.com/socialmedia-stats/all/indonesia. [Accessed: 15-Nov-2020].

[5] “Ini 8 Destinasi Wisata Indonesia yang Paling 'Hits' di Media Sosial Halaman all - Kompas.com.” [Online]. Available: https://travel.kompas.com/read/2019/11/11/220000927/ini-8-destinasi-wisata-indonesia-yang-palinghits-di-media-sosial?page=all. [Accessed: 15-Nov-2020].

[6] "EMBUNG TELOKE - Tempat Wisata Paling Kren di Batulayar | Website Resmi Kantor Desa Batulayar." [Online]. Available: https://www.desabatulayar.id/informasi-publik/informasi/491/wisata-embung-teloke.html. [Accessed: 25-Nov-2020].

[7] I. N. A. F. Setiawan, I. G. Mudana, K. A. Ariningsih, and I. D. A. A. T. Pramawati, "Visualisasi Buku Kepariwisataan dan Persoalan Filsafat Ilmu Terapan Pariwisata," J. Nawala Vis., vol. 2, no. 2, pp. 27-34, 2020.

[8] A. M. Rifiyan and Y. Manullang, "Pelaksanaan Promosi Kepariwisataan Samosir Oleh Dinas Pariwisata, Seni Dan Budaya Kabupaten Samosir,” Riau University, 2015.

[9] T. Sudarmadi, "Pengembangan Potensi Kepariwisataan Berbasis Masyarakat di Desa Pengkol, Kabupaten Sukoharjo, Jawa Tengah," Bakti Budaya, vol. 1, no. 1, pp. 73-91, 2018.

[10] N. Kurniasari, "Strategi Penanganan Krisis Kepariwisataan dalam Kebijakan Badan Nasional Penanggulangan Bencana (BNPB)," Mediat. J. Komun., vol. 10, no. 2, pp. 177-189, 2017.

[11] M. Y. Luckvani, "Pengaruh Kualitas Informasi Kepariwisataan di Media Sosial Daring Facebook dan Instagram pada Citra Destinasi Wisata." Universitas Gadjah Mada, 2019.

[12] S. Larita, A. Halik, and K. Tajibu, "Instagram sebagai Media Promosi Dinas Kebudayaan dan Kepariwisataan Sulawesi Selatan," Washiyah J. Kaji. Dakwah dan Komun., vol. 1, no. 1, 2020.

[13] M. A. Ulfa, B. Irmawati, and A. Y. Husodo, "Twitter Sentiment Analysis using Na” ive Bayes Classifier with Mutual Information Feature Selection,” J. Comput. Sci. Informatics Eng., vol. 2, no. 2, pp. 106-111, 2018.

[14] B. R. Setiawan, I. G. Pasek, S. Wijaya, and D. Ermansyah, "MemPosting Informasi pada Website SMKN 5 Kota Mataram ( Posting Information on SMKN 5 Mataram Website )," J. Begawe Teknol. Inf., vol. 1, no. 1, pp. 2431,2020 . 